\title{
Epicardial adipose tissue measured by magnetic resonance imaging predicts abnormal adenosine stress cardiovascular magnetic resonance imaging and future adverse cardiovascular events
}

\author{
Jason J Lamanna ${ }^{2,4^{*}}$, Chesnal D Arepalli ${ }^{3}$, Agathi R Vrettou' ${ }^{1}$ Emily L Ebert ${ }^{2}$, Arash Harzand ${ }^{2}$, Emir Veledar ${ }^{1}$, \\ John N Oshinski ${ }^{3,4}$, Stamatios Lerakis ${ }^{1}$
}

From 16th Annual SCMR Scientific Sessions

San Francisco, CA, USA. 31 January - 3 February 2013

\section{Background}

A growing body of evidence demonstrates a quantitative association between Epicardial Adipose Tissue (EAT), cardiometabolic risk factors and measures of coronary artery disease (CAD). It is still unclear, however, if EAT is predictive of abnormal functional stress tests and clinical outcomes. The aim of this study is to elucidate the relationship between the total volume of EAT, the detection of ischemia and/or infarct with Adenosine Stress Cardiovascular Magnetic Resonance imaging (AS-CMR), and combined future adverse cardiovascular events.

\section{Methods}

Sixty-one patients, who presented to the emergency department with symptoms suggestive of CAD and were evaluated by AS-CMR, were enrolled in the study. Total volume of EAT was quantified with axial Half Fourier Acquisition Single shot Turbo spin Echo (HASTE) MR images using a rapid semi-automated threshold technique and commercial software. EAT volume was normalized to body Weight (EAT/W). The detection of ischemia and/or infarct by AS-CMR was considered an abnormal exam. Patients were followed by medical record review. The primary end-point was the composite of measured future adverse cardiovascular events: cardiac death, nonfatal myocardial infarction, obstructive CAD visualized with invasive coronary angiography, cerebrovascular accident, heart failure, arrhythmia, or recurrent chest pain of cardiac origin requiring hospital admission.

${ }^{2}$ Medicine, Emory University, Atlanta, GA, USA

Full list of author information is available at the end of the article

\section{Results}

Total EAT volume and EAT/W were significantly increased in the 4/61 (6.6\%) patients with abnormal ASCMR compared to the patients with a normal exam (157 \pm $42 \mathrm{~mm} 3$ vs. $97 \pm 39 \mathrm{~mm} 3, \mathrm{p}=0.0046$ and $1.9 \pm 0.6$ vs. $1.2 \pm 0.6, \mathrm{p}=0.0091$, respectively). Total EAT volume and EAT/W were also significantly increased in patients reaching the primary endpoint $(16 / 61,26.2 \%)$ compared to those without observed events $(129 \pm 43 \mathrm{~mm} 3$ vs. $91 \pm 37$ $\mathrm{mm} 3, \mathrm{p}=0.0014$ and $1.6 \pm 0.6$ vs. $1.1 \pm 0.5, \mathrm{p}=0.0040$, respectively).

\section{Conclusions}

Patients with an abnormal AS-CMR exam had significantly increased volume of EAT. Furthermore, patients with increased volume of EAT experienced significantly more future adverse cardiovascular events. Based on these results, EAT volume measured by CMR may become an important prognostic factor for cardiac risk stratification that should be measured and reported with every CMR study.

\section{Funding}

N/A.

\begin{abstract}
Author details
'Cardiology, Emory University, Atlanta, GA, USA. ${ }^{2}$ Medicine, Emory University, Atlanta, GA, USA. ${ }^{3}$ Radiology, Emory University, Atlanta, GA, USA. ${ }^{4}$ Biomedical Engineering, Emory University/Georgia Institute of Technology, Atlanta, GA,
\end{abstract} USA.

Published: 30 January 2013 
doi:10.1186/1532-429X-15-S1-P274

Cite this article as: Lamanna et al.: Epicardial adipose tissue measured by magnetic resonance imaging predicts abnormal adenosine stress cardiovascular magnetic resonance imaging and future adverse cardiovascular events. Journal of Cardiovascular Magnetic Resonance 2013 15(Suppl 1):P274.

Submit your next manuscript to BioMed Central and take full advantage of:

- Convenient online submission

- Thorough peer review

- No space constraints or color figure charges

- Immediate publication on acceptance

- Inclusion in PubMed, CAS, Scopus and Google Scholar

- Research which is freely available for redistribution

Submit your manuscript at www.biomedcentral.com/submit 